\title{
Physiological energetics of mussel larvae (Mytilus edulis). II. Food uptake
}

\author{
Martin Sprung* \\ Biologische Anstalt Helgoland, Meeresstation, D-2192 Helgoland, Federal Republic of Germany
}

\begin{abstract}
Food uptake of marine mussel larvae (Mytilus edulis L.) was estimated in relation to larval size, temperature $\left(6,12,18^{\circ} \mathrm{C}\right)$ and food concentration $(1,2,5,10,20$ and 40 Isochrysis galbana cells $\mu 1^{-1}$ ). Filtration rates were maximal at low food concentrations (between 1 and 5 cells $\mu 1^{-1}$ ). This was called 'filtration capacity' and expressed as a function of larval size. Ingestion rates reached a plateau with increasing food concentration above 10 cells $\mu l^{-1}$. Maximum rates were called 'ingestion capacity' and expressed as weight and volume of particles passed through the gut. When previously starved larvae enter a food suspension of more than 10 cells $\mu{ }^{1}$, ingestion rate overshoots the ingestion capacity level for up to $1.5 \mathrm{~h}$ at $12^{\circ} \mathrm{C}$. This is caused by filling of the gut, because it was not paralleled by an overshoot of the filtration rate above the filtration capacity level. Particles between 1 and $9 \mu \mathrm{m}$ diameter were taken up, with maximum retention efficiency at about $3.5 \mu \mathrm{m}$ particle diameter.
\end{abstract}

\section{INTRODUCTION}

Food uptake of filter feeders can be characterized by their filtration and ingestion rate. These vary with many environmental factors. Among them, food concentration is of outstanding importance. With food concentration as a variable, filtration and ingestion rates interact in a particular way. Basic features have been outlined, e.g. by Winter (1978) for adult bivalves.

Planktonic larvae of the marine mussel Mytilus edulis must take up food in order to complete their development. They are referred to as planktotrophic according to the classifications of Thorson $(1946,1950)$, Ockelmann (1965) and Mileikovsky (1971). They are filter feeders and catch their food by means of the velum which at the same time effects swimming. Strathmann et al. (1972) described the feeding apparatus as 'opposed band system'; by means of 2 ciliary bands the food particles are brought into a food groove which lies between them. There the food is ensnared and transported to the mouth.

Feeding of bivalve larvae (especially oyster larvae) has been frequently estimated in aquaculture systems. Experiments were thus conducted at rather high food

\footnotetext{
- Present address: Physiological Ecology Section, Department of Zoology, University of Köln, Weyertal 199, D-5000 Köln 41, Federal Republic of Germany
}

concentrations and ecologically unrealistic high temperatures with regard to temperate zones (e.g. Jørgunsen, 1943; Walne, 1956, 1965, 1966; Wilson, 1980 and Gerdes, 1983).

The first to report feeding rates of Mytilus larvae was Bayne (1965). However, interpretation of his data suffers from the high food densities at which he worked (Riisgård et al., 1980). More recent estimates have been aware of this problem (Riisgård et al., 1981; Jespersen and Olsen, 1982).

Here, ingestion and filtration rates have been examined at various food concentrations and larval sizes at three ecologically realistic temperatures. This is the second paper in a series of 4 whose aim is to examine important components of the energy budget of mussel larvae.

\section{MATERIALS AND METHODS}

\section{Food uptake}

Food uptake was estimated with laboratory-reared larvae. Rearing procedure is described by Sprung (1984a). In order to relate data of food uptake to those of growth and respiration described by Sprung (1984a, b), conditions were standardized with respect to temp- 
erature $\left(6,12\right.$ and $\left.18^{\circ} \mathrm{C}\right)$ and food concentration $(1,2,5$, 10,20 and 40 Isochrysis cells $\mu l^{-1}$ ).

The basic experimental procedure has been adopted from Riisgård et al. (1980). Experiments were conducted in temperature-constant rooms at artificial light. If the experimental temperature deviated from that of rearing, the larvae were adapted to it over 3 to $6 \mathrm{~d}$. The larvae were starved $2 \mathrm{~d}$ before the experiment in order to provide uniform conditions.

Feeding rates were estimated in beakers with about $800 \mathrm{ml} 0.45 \mu \mathrm{m}$ filtered seawater (salinity: 29 to $33 \%$ ). They were aerated in order to provide mixing. Algal concentrations were checked by means of $20 \mathrm{ml} \mathrm{sam}$ ples. They were removed from the well-mixed culture vessel by means of a pipette and counted 5 times in a Coulter Counter (Model TA $\mathrm{II}_{1}, 100 \mu \mathrm{m}$ tube). Besides the experimental beaker a blank of similar algal concentration without larvae was examined.

Data were evaluated by a regression line described by the formula:

Ingestion rate $=-\frac{\bar{c}}{L} \times\left(\frac{d \ln c_{i}}{d t}-\frac{d \ln c_{b}}{d t}\right)$

where $c=$ Algal concentrations in experiment $\left(c_{1}\right)$ and blank test $\left(c_{b}\right)$; at least 6 data points were evaluated after an appropriate adaptation period to the food concentration right at the beginning. In some cases algae had to be added anew during the experiment, if the actual concentration drifted too far away from the desired standard concentration. $t=$ Time $_{\text {; }}$ algal concentration was estimated in intervals of half to several hours. $\mathrm{L}=$ Larval density; it lay between 1 (large mussels) and about 20 (small mussels) $\mathrm{ml}^{-1}$; large mussels were counted individually; larval densities of the smaller ones were estimated by sampling 16 times $1 \mathrm{ml}$ from the experimental beaker. $\overrightarrow{\mathrm{c}}=$ Arithmetic mean of all cell concentrations estimated for a regression line; the otherwise logical geometric mean would have stressed the underestimation of the algal concentration which influences food uptake. Due to digestive processes it is the food condition some time before which influences the feeding behaviour rather than the actually registered.

\section{Retention efficiency}

Filtration rate was estimated simultaneously for different size fractions by means of a Coulter Counter. The experimental setup was basically the same as for the food uptake. At the beginning of the experiment a suspension with about the same volume (product of particle number and particle volume) for each size fraction was mixed. For this the following particles were used: a coccolithophoride ( $\varnothing 9$ to $14 \mu \mathrm{m})$ Isochry- sis $(\varnothing 3$ to $7 \mu \mathrm{m})$, Chlorella $(\varnothing 2.8$ to $5.7 \mu \mathrm{m})$ and unspecific particles in the seawater $(<3 \mu \mathrm{m})$. Filtration rates were compared with a blank test. The channel of the Coulter Counter with the highest rate was defined as $100 \%$

Two spectra of this kind have been recorded: one at $12^{\circ} \mathrm{C}$ ( 2 data points evaluated for each channel), the other at $18^{\circ} \mathrm{C}$ ( 3 data points evaluated for each channel). The data were fitted by the least square method to a second order polynomial equation. Subsequently the maximum was corrected to $100 \%$. As no differences were to be expected, both graphs have been included in one

\section{RESULTS}

\section{Retention efficiency}

Retention efficiency was maximal at a particle diameter of $3.5 \mu \mathrm{m}$ (Fig. 1). Particles down to $1 \mu \mathrm{m}$ diameter were retained with declining efficiency. The maximum ingestable particle size lay at about $9 \mu \mathrm{m}$ diameter. In an additional experiment it could be demonstrated that the alga Scripsiella faeröense (diameter: about 20 to $25 \mu \mathrm{m}$ ) could not be ingested. The larvae had permanently empty guts.

\section{Food uptake}

For comparison with data of growth and respiration, the data on food uptake had to be transformed twice: (1) To bring them exactly to the standard food concentration (see 'Materials and Methods'), the data were interpolated in a plot of ingestion rate versus food concentration for each larval size tested (Fig. 2). The graphs have been fitted by eye, because all mathematical descriptions tested implied artificial trends. (2) Data from this plot (Table 2) were related to shell length for each standardized food concentrations and fitted with an allometric equation. The constants are given in Table 3 . Calculations in subsequent papers are based on these equations.

\section{Filtration}

Filtration rates were calculated from the ingestion rates in Fig. 2 for the standard food concentrations:

$$
\text { Filtration rate }=\frac{\text { Ingestion rate }}{\text { Particle concentration }}
$$

The typical interrelation between filtration and ingestion has been described in Fig. 3: the ingestion 
Fig. 1. Mytilus edulis, larvae. Size diagram: 2 spectra and their original data; lower diagram: mean of both spectra corrected to a maximum of $100 \%: y=-49.31+49.89 x-$ $4.17 \mathrm{x}^{2} \cdot \mathrm{x}$ : channel of Coulter Counter; $y$ : retention efficiency ( $\%$ of the maximum); $r^{2}$ : correlation coefficient spectrum of particle retention; upper

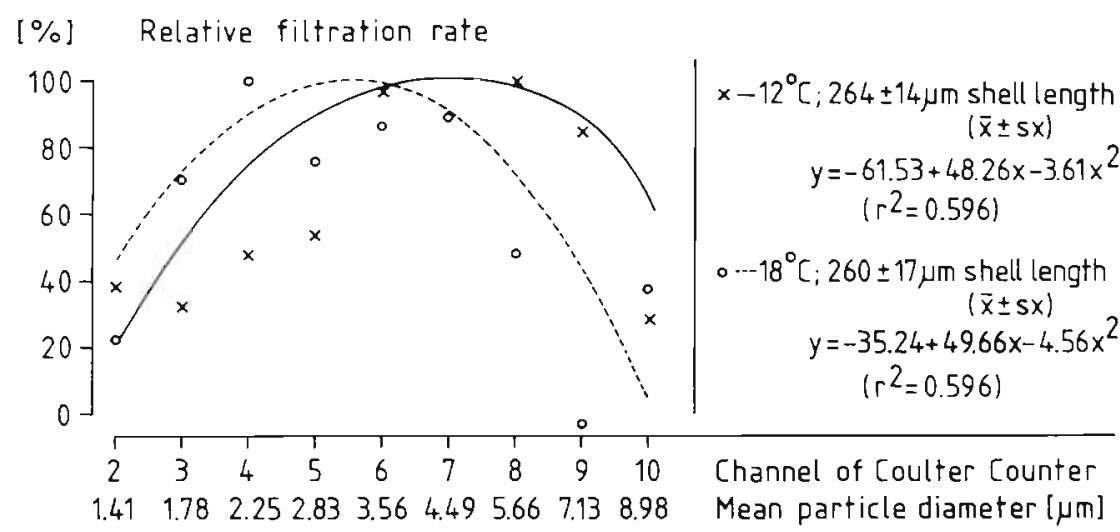

$[\%]$ Relative filtration rate

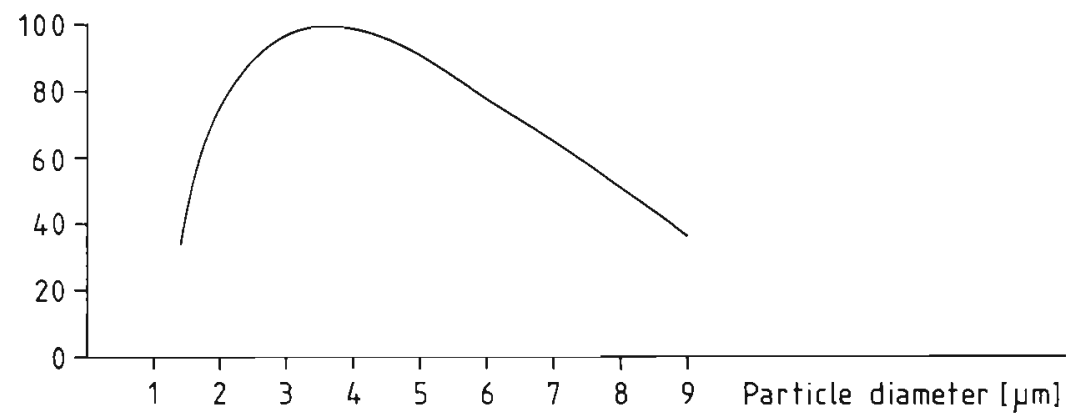

rate increases until attaining a plateau at 10 Isochrysis cells $\mu \mathrm{l}^{-1}$. The filtration rate decreases with the particle concentration at higher Isochrysis densities. At low particle concentrations, the trend is reversed. The latter phenomenon has been interpreted as an experimental artifact (see 'Discussion').

Maximum filtration rates are considered an estimate of the filtration capacity (marked in Table 1). For 2 reasons this assumption must be valid: first of all the amount of food ingested is probably not yet limiting for the food uptake, because a plateau in the ingestion rate has not yet been attained (Fig. 2). Secondly, the cell size of Isochrysis (mean diameter estimated as $4.6 \mu \mathrm{m}$ with a Coulter Counter) is retained with nearly maximum efficiency. Estimates of the filtration capacity at different temperatures and larval sizes have been graphically displayed in Fig. 4.

Table 1. Mytilus edulis, larvae. Filtration rates at various shell lengths, food concentrations (Isochrysis cells $\mu \mathrm{l}^{-1}$ ) and temperatures; data from Fig. 2i maximum values are marked

\begin{tabular}{|c|c|c|c|c|c|c|c|}
\hline \multirow{2}{*}{$\begin{array}{l}\text { Tempera- } \\
\text { ture }\end{array}$} & \multirow{2}{*}{$\begin{array}{l}\text { Shell length } \\
\qquad(\mu \mathrm{m})\end{array}$} & \multicolumn{6}{|c|}{ Filtration rate $\left(\mu \mathrm{l} \mathrm{h}^{-1}\right)$} \\
\hline & & 1 c. $\mu l^{-1}$ & 2 c. $\mu \mathrm{l}^{-1}$ & 5 c. $\mu 1^{-1}$ & 10 c. $\mu l^{-1}$ & 20 c. $\mu l^{-1}$ & $40 \mathrm{c} \cdot \mu \mathrm{l}^{-1}$ \\
\hline \multirow{3}{*}{$6^{\circ} \mathrm{C}$} & 139 & 5.0 & 5.5 & 3.6 & 2.3 & 1.6 & 0.8 \\
\hline & 196 & 6.0 & 15.5 & 8.4 & 3.7 & 1.7 & 0.8 \\
\hline & 261 & 7.0 & 24.0 & 12.6 & 8.3 & 5.1 & 3.4 \\
\hline \multirow{6}{*}{$12^{\circ} \mathrm{C}$} & 141 & 15.0 & 19.0 & 13.8 & 6.6 & 2.9 & 1.2 \\
\hline & 187 & 10.0 & 18.0 & 19.4 & 13.0 & 8.5 & 3.8 \\
\hline & 219 & 17.0 & 37.5 & 19.8 & 11.3 & 6.1 & 3.2 \\
\hline & 229 & 40.0 & 45.0 & 69.8 & 36.6 & 17.0 & 6.3 \\
\hline & 251 & 25.0 & 43.5 & 73.0 & 42.2 & 19.9 & 6.9 \\
\hline & 286 & 37.0 & 85.0 & 72.6 & 35.7 & 15.8 & 6.3 \\
\hline \multirow{4}{*}{$18^{\circ} \mathrm{C}$} & 156 & 19.0 & 15.5 & 12.4 & 8.2 & 4.4 & 2.1 \\
\hline & 186 & - & - & 50.0 & 25.0 & 12.5 & 6.3 \\
\hline & 195 & 37.0 & 28.6 & 19.4 & 11.1 & 6.1 & 3.2 \\
\hline & 245 & 5.0 & 35.0 & 42.0 & 34.0 & 21.5 & 11.0 \\
\hline
\end{tabular}



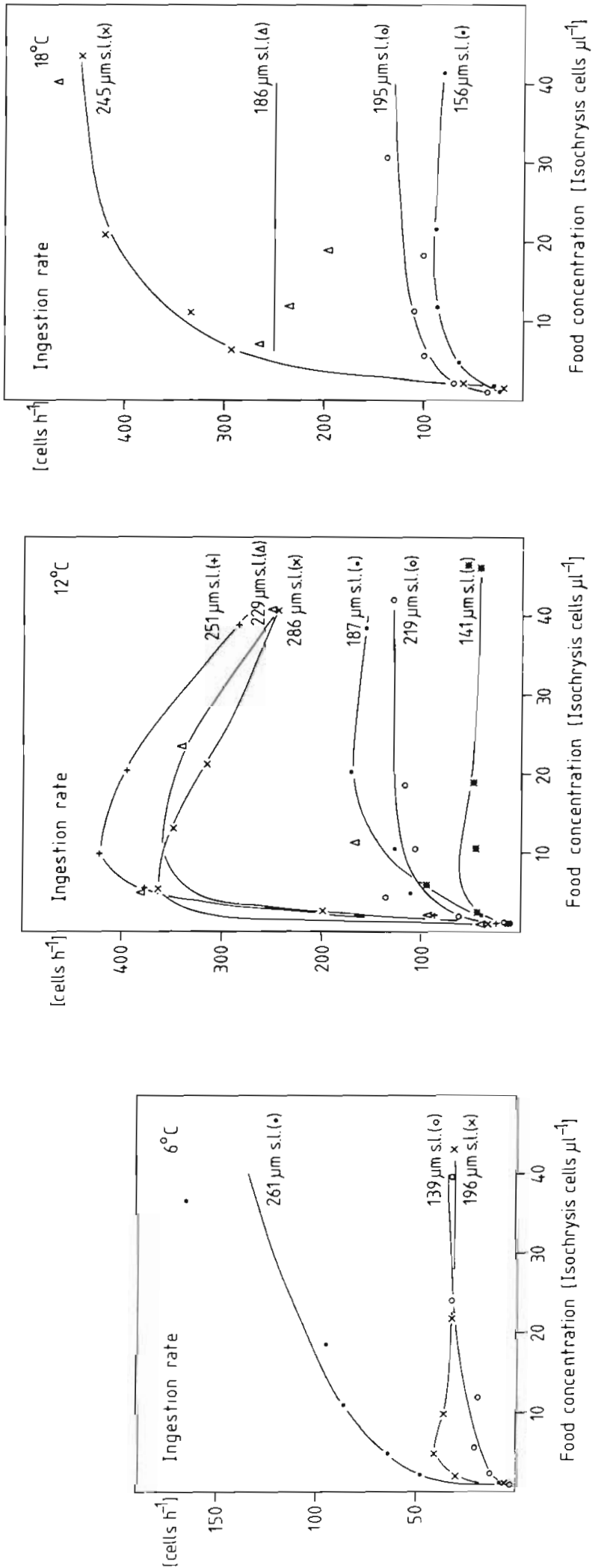

Fig. 2. Mytilus edulis, larvae. Estimates of the ingestion rate at various food concentrations, temperatures and larval sizes (s.l.: shell length); curves fitted by eye

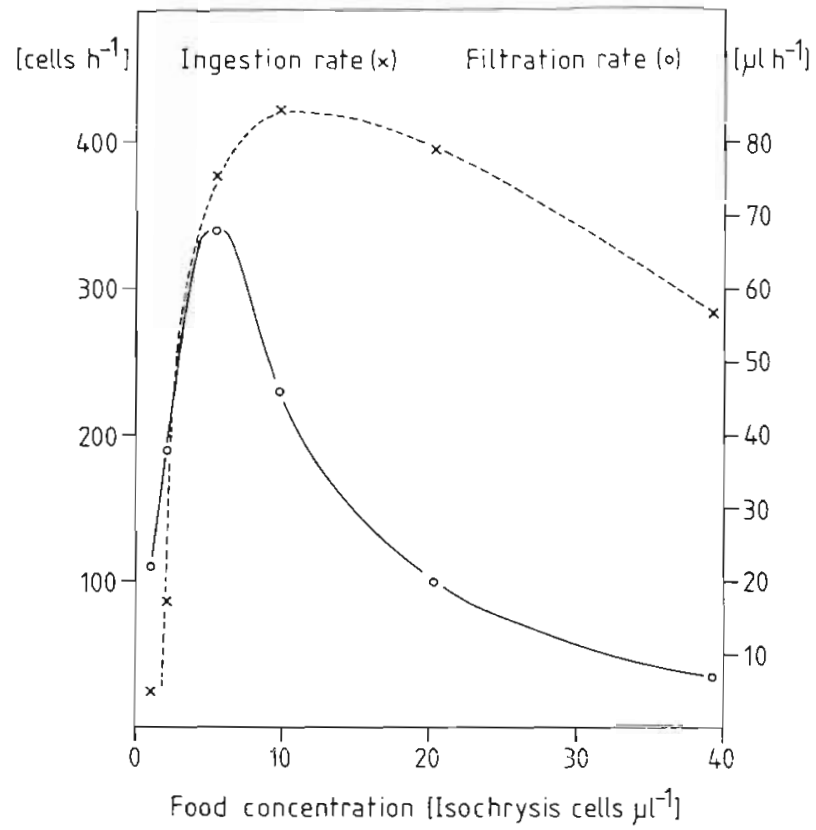

Fig. 3. Mytilus edulis, larvae of $251 \mu \mathrm{m}$ shell length. Interrelation between ingestion and filtration rate at $12^{\circ} \mathrm{C}$

\section{Ingestion}

Ingestion rates at standard food concentrations have been compiled in Table 2. Data in brackets have been corrected assuming that the filtration rate is maintained on the filtration capacity level.

Maximum ingestion rates are marked. In this context they are called 'ingestion capacity'. It denotes the maximum amount of food the larva can ingest under the conditions given. Fig. 5 depicts ingestion capacity as a function of shell length at the 3 standard temperatures. Ingestion capacity has been expressed in 3 ways: as Isochrysis cells ingested per time unit, as volume ingested per time unit (1 Isochrysis cell was estimated as $50 \mu \mathrm{m}^{3}$ with the Coulter Counter), and as percentage of body weight per time unit.

Temperature influences ingestion capacity strongly between 6 and $12^{\circ} \mathrm{C}$, only to a minor extent between 12 and $18^{\circ} \mathrm{C}$. The same is true for the filtration capacity and is also reflected by growth rates previously reported (Sprung, 1984a).

\section{Food uptake after a starvation period}

All estimates referred to up to now, have been longterm rates. In the $12^{\circ} \mathrm{C}$-experiments the feeding rates directly after entering the food suspension after $2 \mathrm{~d}$ of starvation have also been recorded. Ingestion rates have been related to long-term rates, filtration rates to 


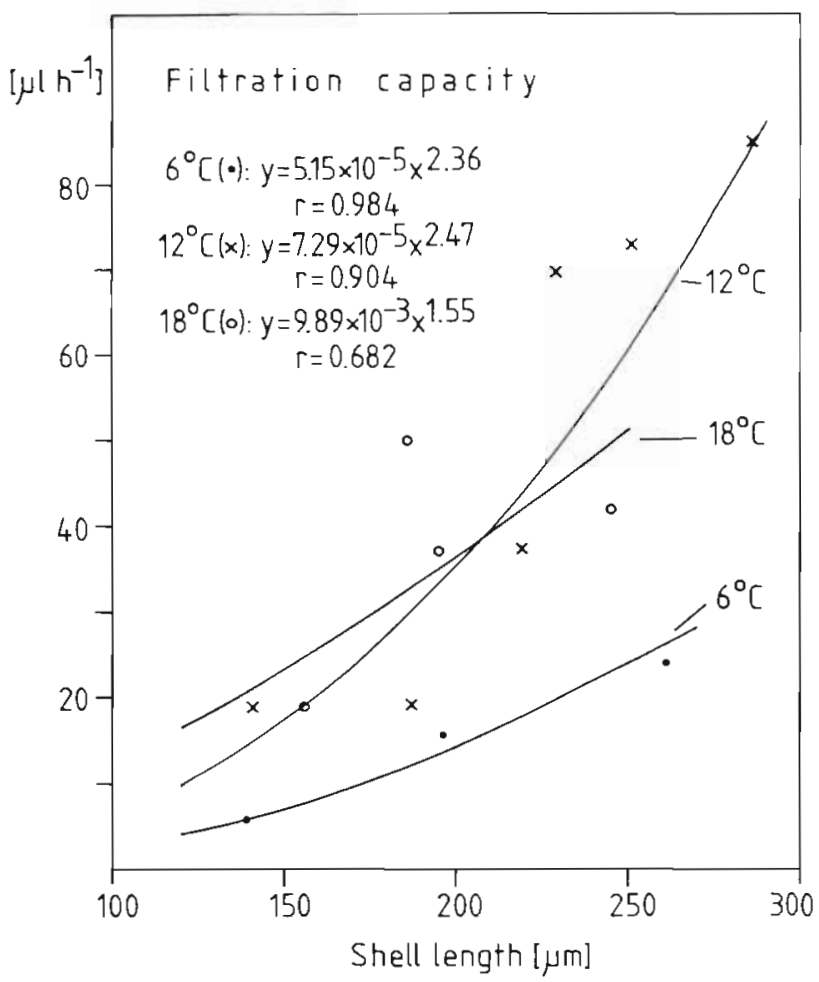

Fig. 4. Mytilus edulis, larvae. Filtration capacity of larvae of various sizes at the experimental temperatures (data points see Table 1); $\mathrm{x}$ : shell length $(\mu \mathrm{m}) ; \mathrm{y}$ : filtration capacity $\left(\mu 1 \mathrm{~h}^{-1}\right)$; r: correlation coefficient

the filtration capacity calculated for the particular larval size (from Table 1). The rates have been artificially subdivided in intervals of half hours, because the samples had often not been taken exactly at these points of the time scale.
The arithmetic mean of each time interval of 5 larval sizes examined are presented in Fig. 6. It demonstrates that after entering a particle concentration of more than 10 Isochrysis cells $\mu l^{-1}$, the ingestion rate is abnormally high for up to $1.5 \mathrm{~h}$. This is more pronounced at higher food concentrations. The overshoot in ingestion is not caused by an overshoot of the filtration rate above the filtration capacity.

\section{DISCUSSION}

Food uptake as a function of food concentration estimated here resembles greatly the results found by other authors for many filter feeding animals: e.g. ciliate Stentor coerulus (Wenzel and Liebisch, 1975), bryozoan Zoobotryon verticillatum (Bullivant, 1968), rotifer Brachionus plicatilis (Chotiyaputta and Hirayama, 1978), adult freshwater and marine mussels, Dreissena polymorpha (Walz, 1978) and Mytilus edulis (Winter, 1973), brine shrimp Artemia salina (Reeve, 1963), copepod Calanus pacificus (Frost, 1972) and the cladocerans Daphnia pulex (Geller, 1975) and Daphnia magna (Rigler, 1961; Kersting and v. d. Leeuw, 1976; Porter et al., 1982). Roughly, their behaviour can be separated in 2 distinct patterns: food uptake in dilute food concentrations and food uptake in dense food concentrations.

\section{Food uptake in dense food concentrations}

This is characterized by a constant ingestion rate over a wide range of food concentrations and a declin-

Table 2. Mytilus edulis, larvae. Ingestion rates at various shell lengths, food concentrations (Isochrysis cells $\mu \mathrm{l}^{-1}$ ) and temperatures; data from Fig. 2; values in brackets have been calculated for no reduction in filtration rate at low food concentrations (see also text); marked are the maximum estimates

\begin{tabular}{|c|c|c|c|c|c|c|c|c|c|}
\hline \multirow{2}{*}{$\begin{array}{l}\text { Tempera- } \\
\text { ture }\end{array}$} & \multirow{2}{*}{$\begin{array}{l}\text { Shell length } \\
\qquad(\mu \mathrm{m})\end{array}$} & \multicolumn{8}{|c|}{ Ingestion rate (Isochrysis cells $\mathrm{h}^{-1}$ ) } \\
\hline & & \multicolumn{2}{|c|}{1 c. $\mu l^{-1}$} & \multicolumn{2}{|c|}{$2 c \cdot \mu]^{-1}$} & 5 c. $\mu l^{-1}$ & 10 c. $\mu \mathrm{l}^{-1}$ & 20 c. $\mu \mathrm{l}^{-1}$ & $40 \mathrm{c} \cdot \mu \mathrm{l}^{-1}$ \\
\hline \multirow{3}{*}{$6^{\circ} \mathrm{C}$} & 139 & 5 & (6) & 11 & & 18 & 23 & 31 & 32 \\
\hline & 196 & 6 & $(16)$ & 31 & & 42 & 37 & 33 & 32 \\
\hline & 261 & 7 & (24) & 48 & & 63 & 83 & 101 & 135 \\
\hline \multirow{6}{*}{$12^{\circ} \mathrm{C}$} & 141 & 15 & (19) & 38 & & 69 & 66 & 57 & 47 \\
\hline & 187 & 10 & (19) & 36 & (39) & 97 & 130 & 170 & 153 \\
\hline & 219 & 17 & (38) & 75 & & 99 & 113 & 122 & 129 \\
\hline & 229 & 40 & (70) & 90 & (140) & 349 & 366 & 340 & 252 \\
\hline & 251 & 25 & (73) & 87 & (146) & 365 & 422 & 397 & 277 \\
\hline & 286 & 37 & (85) & 170 & & 363 & 357 & 316 & 250 \\
\hline \multirow{4}{*}{$18^{\circ} \mathrm{C}$} & 156 & 19 & (19) & 31 & & 73 & 86 & 88 & 84 \\
\hline & 186 & - & & - & & 250 & 250 & 250 & 250 \\
\hline & 195 & 37 & (37) & 70 & & 102 & 110 & 120 & 124 \\
\hline & 245 & 5 & (42) & 70 & (84) & 240 & 320 & 414 & 442 \\
\hline
\end{tabular}



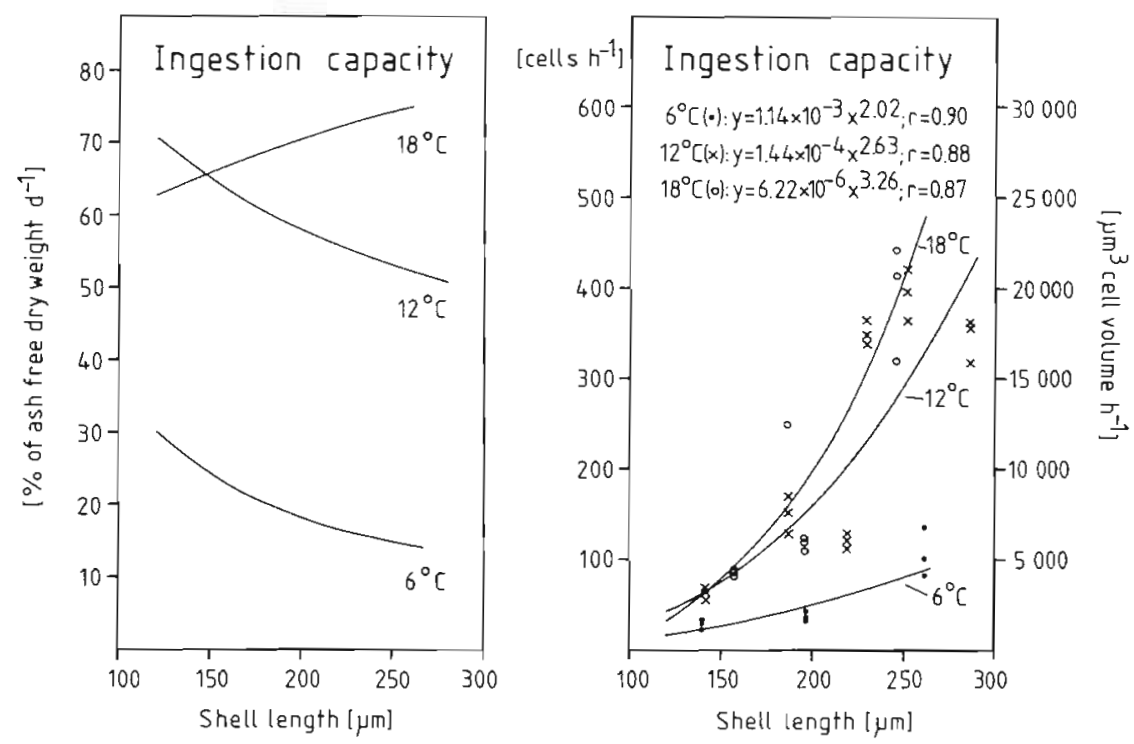

Fig. 5. Mytilus edulis, larvae. Ingestion capacity of larvae of different sizes at the experimental temperatures; data points see Table $2 ; y$ : ingestion capacity (cells $\mathrm{h}^{-1}$ ); $\mathrm{x}$ : shell length $(\mu \mathrm{m})$; r: correlation coefficient; see also text

ing filtration rate with increasing food concentration. I have called this particular constant ingestion rate the ingestion capacity in this context. It is limited by the passage of the food through the gut. That is why the volume of food ingested describes it better rather than its weight or energy content. However, next to other variables (e.g. temperature) the ingestion capacity depends also on the digestibility of the food, as pointed out by McMahon and Rigler (1965) for daphnids.

As not all the food filtered out can be ingested, a certain part must be rejected. This can be effected either by the cilia (Strathmann et al., 1972) or in form of pseudofaeces (Yonge, 1926). In the experiments described here, ingestion was only estimated indirectly by recording a particle decrease. Pseudofaeces would have probably also contributed to that particle loss. In the range of food concentrations investigated here, it seems thus more likely that particles have been rejected by the cilia. Otherwise this plateau in ingestion would not have been detected.

In very dense food concentrations, however, the ingestion rate can decrease. This phenomenon could

Table 3. Mytilus edulis, larvae. Constants of the fitted curves: ingestion rate (Isochrysis cells $\mathrm{h}^{-1}$ ) versus shell length (um) at standard food concentrations; based on corrected data from Table 2 i: correlation coefficient; $\mathrm{n}$; number of data points evaluated

\begin{tabular}{|c|c|c|c|c|c|}
\hline \multirow{2}{*}{$\begin{array}{l}\text { Tempera- } \\
\text { ture }\end{array}$} & \multirow{2}{*}{$\begin{array}{l}\text { Food concentration } \\
\left(\text { Isochrysis cells } \mu l^{-1}\right)\end{array}$} & \multicolumn{4}{|c|}{ Ingestion rate $=b \times$ shell length ${ }^{m}$} \\
\hline & & $\mathrm{b}$ & $\mathrm{m}$ & r & $\mathrm{n}$ \\
\hline \multirow{6}{*}{$6^{\circ} \mathrm{C}$} & 1 & $1.11 \times 10^{-4}$ & 2.22 & 0.983 & 3 \\
\hline & 2 & $1.03 \times 10^{-4}$ & 2.36 & 0.984 & 3 \\
\hline & 5 & $9.59 \times 10^{-4}$ & 2.00 & 0.989 & 3 \\
\hline & 10 & $1.03 \times 10^{-3}$ & 2.02 & 0.871 & 3 \\
\hline & 20 & $3.29 \times 10^{-3}$ & 1.82 & 0.863 & 3 \\
\hline & 40 & $4.65 \times 10^{-4}$ & 2.21 & 0.839 & 3 \\
\hline \multirow{6}{*}{$12^{\circ} \mathrm{C}$} & 1 & $6.88 \times 10^{-5}$ & 2.49 & 0.902 & 6 \\
\hline & 2 & $1.47 \times 10^{-4}$ & 2.47 & 0.905 & 6 \\
\hline & 5 & $8.79 \times 10^{-5}$ & 2.71 & 0.853 & 6 \\
\hline & 10 & $8.88 \times 10^{-5}$ & 2.72 & 0.871 & 6 \\
\hline & 20 & $1.33 \times 10^{-4}$ & 2.64 & 0.876 & 6 \\
\hline & 40 & $2.72 \times 10^{-4}$ & 2.48 & 0.913 & 6 \\
\hline \multirow{6}{*}{$18^{\circ} \mathrm{C}$} & 1 & $2.99 \times 10^{-3}$ & 1.75 & 0.928 & 3 \\
\hline & 2 & $5.10 \times 10^{-4}$ & 2.20 & 0.937 & 3 \\
\hline & 5 & $6.55 \times 10^{-4}$ & 2.34 & 0.704 & 4 \\
\hline & 10 & $1.29 \times 10^{-4}$ & 2.67 & 0.786 & 4 \\
\hline & 20 & $7.62 \times 10^{-6}$ & 3.56 & 0.925 & 4 \\
\hline & 40 & $1.29 \times 10^{-6}$ & 3.56 & 0.925 & 4 \\
\hline
\end{tabular}


Fig. 6. Mytilus edulis, larvae. Ingestion and filtration rate in different food densities (Isochrysis cells $\mathrm{h}^{-1}$ ) after a starvation period of 2 days; mean of 5 series at $12^{\circ} \mathrm{C}$ with larvae of different sizes

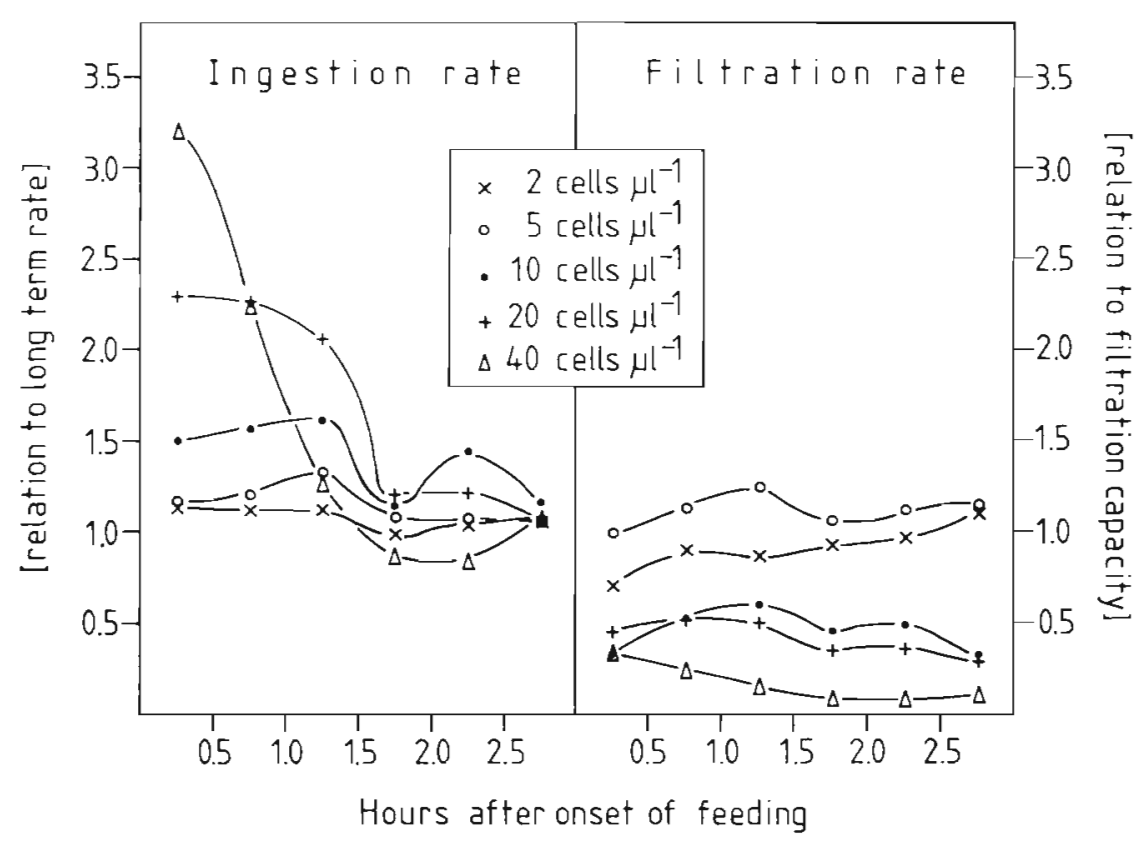

also be noted with data of the $12^{\circ} \mathrm{C}$-experiments. It parallels a decline in growth at that temperature (Sprung, 1984a).

Yonge (1926) has observed that bivalve larvae can entangle themselves in a net of pseudofaeces in dense food suspensions. This restricts motility. This, however, cannot have caused the decrease, because in the 6 and $18^{\circ} \mathrm{C}$-experiments the ingestion rate remained fairly constant in this particular range. The reason may be looked for in dissolved substances produced by the Isochrysis culture; they are known to be toxic for bivalve larvae under special conditions (Guillard, 1958). Production may have been reduced in the 6 and $18^{\circ} \mathrm{C}$-experiments because of the temperature change (cultivation at $10^{\circ} \mathrm{C}$ ).

Ingestion capacity levels can only be estimated in long-term experiments. When entering a dense food suspension after a starvation period, the ingestion rate can show an overshoot with abnormally high short term values (Fig. 6). This phenomenon has frequently been observed with planktonic organisms, e.g. copepods (Mullin, 1963; McAllister, 1970, 1971; Frost, 1972), cladocerans (McMahon and Rigler, 1965; Geller, 1975), and rotifers (Schlosser and Anger, 1982). It is just the filling of the empty gut which causes this experimental feature. By means of this behavioural mode planktonic animals can optimize uptake of patchy distributed food.

\section{Food uptake in dilute food concentrations}

This is characterized by a constant filtration rate and an increase of ingestion rate with increasing food con- centration. I have called this particular filtration rate 'filtration capacity' in this context: it is the filtration rate which is not restricted by the process of food ingestion. For mussel larvae the transition from 'dilute' to 'dense' food concentrations (the incipient limiting level) lies between 5 and 10 Isochrysis cells $\mu \mathrm{l}^{-1}$. In most cases filtration rates of bivalve larvae have been previously estimated in higher particle densities. Although this provides a reasonable estimate of the ingestion capacity, filtration capacity has been frequently underestimated (Table 4).

A decrease of the filtration rate at vегy low particle concentrations has been discussed controversely in the literature, since it had been first described by Adams and Steele (1966) and Parsons et al. (1967) for copepods. Computer models have demonstrated that this behaviour makes sense. Filtration is an energy consuming process. If filtration activity is only enhanced when a certain amount of food particles is present in the water, this serves in economizing the behaviour (Lam and Frost, 1976; Lehman, 1976).

It seems doubtful that this argument is also valid for mussel larvae. Although feeding of bivalve larvae can probably be stopped whilst continuing to swim (Strathmann et al., 1972), this cannot mark a significant saving of energy, because the cilia have to move anyhow. If this is so, why should the larva not make use of those few food particles which it needs so urgently in a nutritionally dilute environment?

The apparent reduction in filtration activity is probably caused by a process which one tends to ignore when estimating food uptake with a particle counter. Next to the divisoin of the food alga, particles can enter into the experimental system by many sources, e.g. by 
Table 4a. Bivalve larvae. Filtration rates reported in literature

\begin{tabular}{|c|c|c|c|c|c|c|}
\hline Species & $\begin{array}{l}\text { Shell } \\
\text { length } \\
(\mu \mathrm{m})\end{array}$ & $\begin{array}{c}\text { Tempera- } \\
\text { ture } \\
\left({ }^{\circ} \mathrm{C}\right)\end{array}$ & $\begin{array}{l}\text { Food con- } \\
\text { centration } \\
\text { (cells } \mu l^{-1} \text { ) }\end{array}$ & Food alga & $\begin{array}{l}\text { Filtration } \\
\text { rate }\left(\mu \mathrm{l} \mathrm{h}^{-1}\right)\end{array}$ & Source \\
\hline Ostrea edulis & 200 & $20-22$ & $15-26$ & 'flagellates' & 27.1 & $\begin{array}{l}\text { Jørgensen (1943) with data } \\
\text { from Bruce et al. (1940) }\end{array}$ \\
\hline Ostrea edulis & $218-280$ & $19-25$ & $31-54$ & Isochrysis & $18-20$ & Walne (1956) \\
\hline Ostrea edulis & 219 & $23-24$ & $8-123$ & Isochrysis & $15-42$ & Walne (1965) \\
\hline Ostrea edulis & $178-184$ & 24 & $8-230$ & Isochrysis & $0.8-10$ & Walne (1965) \\
\hline Ostrea edulis & 231 & $21-22$ & $0-123$ & Isochrysis & $13.8-27.5$ & Walne (1965) \\
\hline Ostrea edulis & $180-260$ & 21 & $20-50$ & Isochrysis & $12.5-25.0$ & Walne (1966) \\
\hline Ostrea edulis & 228 & $?$ & $50-400$ & Isochrysis & $0.3-9$ & Wilson (1980) \\
\hline Ostrea edulis & 250 & $?$ & $40-220$ & Dunaliella & $1.8-5.4$ & Wilson (1980) \\
\hline Crassostrea gigas & $87-151$ & 25 & 100 & Isochrysis & $2.8-7.0$ & Gerdes (1983) \\
\hline Crassostrea gigas & $89-294$ & 25 & $50+50$ & $\begin{array}{l}\text { Isochrysis + } \\
\text { Chaetoceros }\end{array}$ & $2.3-93.5$ & Gerdes (1983) \\
\hline Mytilus edulis & $170-260$ & 18 & $25-380$ & Isochrysis & $4-25$ & Bayne (1965) \\
\hline Mytilus edulis & 260 & 16 & 64 & Isochrysis & 12.5 & Bayne (1965) \\
\hline Mytilus edulis & 260 & 11 & 60 & Isochrysis & 2 & Bayne (1965) \\
\hline Mytilus edulis & 150 & 12 & $1.5-5.5$ & Isochrysis & 11.4 & Ríisgård et al. (1980) \\
\hline Mytilus edulis & $120-250$ & 15 & $3-6$ & $\begin{array}{l}\text { Isochrysis + } \\
\text { Monochrysis }\end{array}$ & $16.2-141$ & Riisgård et al. (1981) \\
\hline Mytilus edulis & $120-250$ & $17-19$ & $3-12$ & $\begin{array}{l}\text { Isochrysis + } \\
\text { Monochrysis }\end{array}$ & $10.6-85.3$ & $\begin{array}{l}\text { Jespersen and Olsen } \\
\text { (1982) }\end{array}$ \\
\hline Mytilus edulis & $120-250$ & 6 & $1-5$ & Isochrysis & $4-21$ & This paper \\
\hline Mytilus edulis & $120-250$ & 12 & $1-5$ & Isochrysis & $10-61$ & This paper \\
\hline Mytilus edulis & $120-250$ & 18 & $1-5$ & Isochrysis & $17-52$ & This paper \\
\hline
\end{tabular}

Table $4 \mathrm{~b}$. Bivalve larvae. Ingestion rates reported in literature

\begin{tabular}{|c|c|c|c|c|c|}
\hline Species & $\begin{array}{l}\text { Shell length } \\
(\mu \mathrm{m})\end{array}$ & $\begin{array}{l}\text { Temperature } \\
\left({ }^{\circ} \mathrm{C}\right)\end{array}$ & Food alga & $\begin{array}{l}\text { Ingestion rate } \\
\text { (cells } \mathrm{h}^{-1} \text { ) }\end{array}$ & Source \\
\hline Ostrea edulis & $180-195$ & $20-22$ & 'Flagellate I' & 1000 & Bruce et al. (1940) \\
\hline Ostrea edulis & $218-280$ & $19-25$ & Isochrysis & 1040 & Walne $(1956,1959)$ \\
\hline Ostrea edulis & $178-184$ & 24 & Isochrysis & $133-600$ & Walne (1965) \\
\hline Ostrea edulis & 219 & $23-24$ & Isochrysis & $591-1517$ & Walne (1965) \\
\hline Ostrea edulis & 231 & $21-22$ & Isochrysis & $456-2333$ & Walne (1965) \\
\hline Ostrea edulis & $180-260$ & 21 & Isochrysis & $830-2500$ & Walne (1966) \\
\hline Ostrea edulis & 228 & $?$ & Isochrysis & $90-900$ & Wilson $(1980)$ \\
\hline Crassostrea gigas & $>200$ & 20 & Isochrysis & 2600 & Malouf and Breese (1977) \\
\hline Mytilus edulis & 150 & 12 & Isochrysis & $81-89$ & Riisgărd et al. (1980) \\
\hline Mytilus edulis & $\begin{array}{l}\text { Whole size } \\
\text { spectrum }\end{array}$ & 15 & $\begin{array}{l}\text { Isochrysis }+ \\
\text { Monochrysis }\end{array}$ & $150-800$ & $\begin{array}{l}\text { Jespersen and Olsen } \\
\text { (1982) }\end{array}$ \\
\hline Mytilus edulis & $120-250$ & 6 & Isochrysis & $18-80$ & This paper \\
\hline Mytilus edulis & $120-250$ & 12 & Isochrysis & $41-292$ & This paper \\
\hline Mytilus edulis & $120-250$ & 18 & Isochrysis & $38-408$ & This paper \\
\hline
\end{tabular}

little air bubbles formed by stirring, by faeces or mucus produced by the larvae, by dust particles absorbed onto the water surface and so on. Ingestion rates are only estimated correctly, if these processes have only minor effects in the size spectrum recorded. If the particle peak followed is too small, this assumption is no longer valid. This seems to have been the case at the lowest particle concentration examined.

\section{Size spectrum of food uptake}

Size spectra of food uptake described by means of a Coulter Counter can be biased by the same phenomenon. Utmost care had to be taken for homogeneous particle distribution in these experiments. Nonhomogeneous particle distribution will normally show the highest filtration rate at a particle peak, because 
here particle production is lowest relative to the particle number filtered out. Thus, apparently the mussel selects this particle peak. However, this is an artifact. Any selective modes demonstrated by this experimental setup should be critically regarded (e.g. Wilson, 1980).

The size spectrum of particles retained recorded here agrees with that published by Riisgard et al. (1980) for mussel larvae and Walne (1965) for oyster larvae. Of what particles does the size spectrum between 1 and $10 \mu \mathrm{m}$ diameter consist in the seawater? What is the nutritional value of the food particles?

Small phytoplanktonic organisms

A great deal of them may be made up of naked flagellates. The high nutritional value of many species of flagellates for bivalve larvae has been documented (e.g. Chromulina pleiaides, Isochrysis galbana, Monochrysis lutheri; see Loosanoff and Davis, 1950; Davis and Guillard, 1958; Guillard, 1958; Stickney, 1964; Walne, 1956, 1963, 1964, 1970).

However, according to many literature data on flagellates in near shore seawater, their concentration is far too low to provide a realistic substratum for bivalve larvae to live on (Cole, 1939; Knight-Jones, 1952: Drinkwaard, 1961; Millar, 1961; Durbin et al., 1975; Boalch et al., 1978). Other authors, in contrast, give quite reasonable figures (Throndsen, 1978; Riisgård and Poulsen, 1981; Pedersen [in Jespersen and Olsen, 1982]).

Probably diatoms form only a small part of the larval diet in nature due to their size and morphology (spines, chains, etc.). Exceptions are e.g. Phaeodactylum tricornutum, Chaetoceros calcitrans or Cyclotella nana (Davis and Guillard, 1958; Loosanoff and Davis, 1963; Walne, 1979).

\section{Bacteria}

It dates back to the experiments of Davis (1953) that bacteria are looked upon as inadequate food for bivalve larvae. Besides this, many strains have harmful effects (e g. Walne, 1958; Guillard, 1959; Loosanoff and Davis, 1963; Tubiash et al., 1965; Tubiash, 1972; Brown, 1973; Garland et al., 1983). And, indeed when occurring individually, most bacteria (diameter 0.3 to $0.8 \mu \mathrm{m}$ ) are too small to be ingested by bivalve larvae. Only a few authors have pointed out that bacteria also have nutritional value for them (Imai and Hatanaka, 1949; Hidu and Tubiash, 1963; Martin and Mengus, 1977).

\section{Detritus}

Information on this group is rather conflicting because of its heterogeneous composition. Basically larvae can make use of it as food source, as demonstrated e.g. by Carriker (1956) and Masson (1977). Rearing larvae with artificial detritus in form of dried and pulverized algae has also been successful (Hidu and Ukeles, 1964; Chanley and Normandin, 1967). Other experiments to demonstrate the nutritional value of detritus have failed (Loosanoff et al., 1951; Davis, 1953; Loosanoff, 1954; Loosanoff and Davis, 1963).

Next to particulate food, bivalve larvae can also take up dissolved organic substances, especially dissolved free amino acids (Davis and Chanley, 1956; Ukeles, 1975; Rice et al., 1980; Manahan, 1983). Although having some significance especially during the absence of particulate food in terms of longer survival periods (Gustafson, 1980; Sprung, 1984C), its total contribution to the diet is obviously rather low (Rice et al., 1980).

Thus, although many quantitative aspects of bivalve larval feeding are well documented, at least for defined laboratory conditions, knowledge of its natural diets remains rather speculative.

Acknowledgements. This paper is a contribution to research project 'Experimentelle Marine Okosystemanalyse' sponsored by Bundesministerium für Forschung und Technologie, Bonn (Grant No. MFU-0328/1). It is based on parts of the author's doctoral thesis submitted to Kiel University. I am grateful to Professor Dr. W. Noodt for supervising the thesis, to Dr. K. Anger for helpful discussions of this paper, to Dr. E. Hagmeier for providing the algal cultures for the experiments, and to Dr. M. Rieper for correcting the manuscript. I am also indebted to Studienstiftung des Deutschen Volkes. Bonn-Bad Godesberg for financial support.

\section{LITERATURE CITED}

Adams, J. A., Steele, J. H. (1966). Shipboard experiments on the feeding of Calanus finmarchicus (Gunnerus). In: Barnes, H. (ed.) Some contemporary studies in marine science. George Allen and Unwin Ltd, London, p. 19-35

Bayne, B. L. (1965). Growth and the delay of metamorphosis of the larvae of Mytilus edulis L. Ophelia 2: 1-47

Boalch, G. T., Harbour, D. S., Butler, E. I. (1978). Seasonal phytoplankton in the western English Channel, 1964-1974. J. mar. biol. Ass. U. K. 58: 943-953

Brown, C. (1973). The effects of some selected bacteria on embryos and larvae of the American oyster, Crassostrea virginica. J. Invertebr. Pathol. 21: 215-223

Bruce, J. R., Knight, M., Parke, M. W. (1940). The rearing of oyster larvae on an algal diet. J. mar, biol. Ass. U. K. 24 : 337-374

Bullivant, J. S. (1968). The rate of feeding of the bryozoan Zoobotryon verticillatum. N. Z. Jl mar. Freshwat. Res. 2: 111-134 
Carriker, M. R. (1956). Biology and propagation of young hard clams, Mercenaria mercenaria. J. Elisha Mitchell scient. Soc. 72: $57-60$

Chanley, P., Normandin, R. F. (1967). Use of artificial foods for larvae of the hard clam Mercenaria mercenaria L. Proc. natn. Shellfish. Ass. 57: 31-37

Chotiyaputta, C. Hirayama, K. (1978). Food selectivity of the rotifer Brachionus plicatilis feeding on phytoplankton. Mar. Biol. 45: 105-111

Cole, H. A. (1939). Further experiments in the breeding of oysters (Ostrea edulis) in tanks. Fishery Invest., Lond. II, 16: $1-47$

Davis, H. C. (1953). On food and feeding of larvae of the American oyster, C. virginica. Biol. Bull. mar biol. Lab., Woods Hole 104: 334-350

Davis, H. C., Chanley, P. E. (1956). Effects of some dissolved substances on bivalve larvae. Proc. natn. Shellfish. Ass. 46: $59-74$

Davis, H. C., Guillard, R. R. (1958). Relative value of ten genera of microorganisms as food for oyster and clam larvae. Fishery Bull. Fish Wildl. Serv. U. S. 58: 293-304

Drinkwaard, A. C. (1961). The quality of oysters in relation to environmental conditions in the Oosterschelde in 1959. Ann biol., Copenhague 16: 255-261

Durbin, E. G., Krawiec, R. W., Smayda, T. J. (1975). Seasonal studies on the relative importance of different size fractions of phytoplankton in Narragansett Bay (USA). Mar. Biol. 32: 271-287

Frost, B. W. (1972). Effects of size and concentration of food particles on the feeding behaviour of the marine planktonic copepod Calanus pacificus. Limnol. Oceanogr. 17: 805-815

Garland, C. D., Nash, G. V., Sumner, C. E., McMeekin, T. A (1983). Bacterial pathogens of oyster larvae (Crassostrea gigas) in a Tasmanian hatchery. Aust. J. mar. Freshwat. Res. 34: 483-487

Geller, W. (1975). Die Nahrungsaufnahme von Daphnia pulex in Abhängigkeit von der Futterkonzentration, der Temperatur, der Körpergröße und dem Hungerzustand der Tiere. Arch. Hydrobiol. 48 (Suppl.): 47-107

Gerdes, D. (1983). The Pacific oyster Crassostrea gigas. Part I. Feeding behaviour of larvae and adults. Aquaculture 31 . $195-219$

Guillard, R. R. (1958). Some factors in the use of nannoplankton as food for larval and juvenile bivalves. Proc. natn. Shellfish. Ass. 48: 134-141

Guillard, R. R. (1959). Further evidence of the destruction of bivalve larvae by bacteria. Biol. Bull. mar. biol. Lab., Woods Hole 117: 258-266

Gustafson, R. G. (1980). Dissolved free amino acids in the nutrition of larvae of the soft-shell clam Mya arenaria. M. Sc. thesis, University of Maine, Orono

Hidu, H., Tubiash, H. S. (1963). A bacterial basis for the growth of antibiotic treated bivalve larvae. Proc. natn. Shellfish. Ass. 54: 25-39

Hidu, H., Ukeles, R. (1964). Dried unicellular algae as food for larvae of the hard shell clam, Mercenaria mercenaria. Proc. natn. Shellfish. Ass. 53: 85-101

Imai, T., Hatanaka, M. (1949). On the artificial propagation of the Japanese common oyster, Ostrea gigas Thun. by non colored naked flagellates. Bull. Inst. agric. Res. Tohoku Univ. 1. 33-46

Jespersen, H., Olsen, K. (1982). Bioenergetics in veliger larvae of Mytilus edulis L. Ophelia 21: 101-113

Jorgensen, C. B. (1943). On the water transport through the gills of bivalves. Acta physiol. Scand. 5: 297-304

Kersting, K., van der Leeuw, W. (1976). The use of the Coulter
Counter for measuring the feeding rates of Daphnia magna. Hydrobiologia 49: 233-237

Knight-Jones, E. W (1952). Reproduction of oysters in the rivers Crouch and Roach, Essex, during 1947, 1948 and 1949. Fishery Invest, Lond. II, 18: 2-49

Lam, R. K. Frost, B. W. (1976). Model of copepod filtering response to changes in size and concentration of food Limnol. Oceanogr. 21: 490-500

Lehman, J. T (1976). The filter-feeder as an optimal forager and the predicted shapes of feeding curves. Limnol Oceanogr. 21: 501-516

Loosanoff, V L., Davis, C. (1950). Conditioning Venus mercenaria for spawning in winter and breeding its larvae in the laboratory. Biol. Bull. mar. biol. Lab., Woods Hole 98: $60-65$

Loosanoff, V. L., Miller, W. S., Smith, P. B. (1951). Growth and settling of larvae of Venus mercenaria in relation to temperature. J. mar. Res. 10: 59-81

Loosanoff, V L. (1954). New advances in the study of bivalve larvae. Am. Scient. 42: 607-624

Loosanoff, V L., Davis, C. H. (1963). Rearing of bivalve mollusks. Ady. mar. Biol. 1: 1-136

Malouf, R. E., Breese, W. P. (1977). Food consumption and growth of larvae of the Pacific oyster, Crassostrea gigas (Thunberg), in a constant flow rearing system. Proc, natn. Shellfish. Ass. 67: 7-16

Manahan, D. T. (1983). The uptake and metabolism of dissolved amino acids by bivalve larvae. Biol. Bull. mar. biol. Lab., Woods Hole 164: 236-250

Martin, Y P., Mengus, B. M. (1977). Use of selected bacterial strains for feeding larvae of Mytilus galloprovincialis Lmk in experimental rearing. Aquaculture 10: 253-262

Masson, M. (1977). Observations sur la nutrition des larves de Mytilus galloprovincialis avec des aliments inertes. Mar. Biol. 40: 157-164

McAllister, C. D. (1970). Zooplankton rations, phytoplankton mortality, and the estimation of marine production. In: Steele, J. H. (ed.) Marine food chains. Oliver and Boyd, Edinburgh, p. 419-457

McAllister, C. D. (1971). Some aspects of nocturnal and continuous grazing by planktonic herbivores in relation to production studies. Fish. Res. Bd Can. Tech. Rep. 248

McMahon, J. W., Rigler, F. H. (1965). Feeding rate of Daphnia magna Straus in different foods labelled with radioactive phosphorus. Limnol. Oceanogr. 10: 105-113

Mileikovsky, S. A. (1971). Types of larval development in marine bottom invertebrates, their distribution and ecological significance: a re-evaluation. Mar. Biol. 10: 193-213

Millar, R. H. (1961). Scottish oyster investigations 1946-1958. Mar. Res. Ser Scottish Home Dept. 1961 (3): 1-76

Mullin, M. M. (1963). Some factors affecting the feeding of marine copepods of the genus Calanus. Limnol. Oceanogr. 8: $239-250$

Ockelmann, K. W. (1965). Developmental types in marine bivalves and their distribution along the Atlantic coast of Europe. In: Cox, L. R., Peake, J. F. (ed.) Proceedings of the first European malacological congress, London, 1962 , p. 25-35

Parsons, T. R., LeBrasseur, R. J., Fulton, J. D. (1967). Some observations on the dependence of zooplankton grazing on the cell size and concentration of phytoplankton blooms. J. oceanogr. Soc. Japan 23: 10-17

Porter, K. Ci., Gerritsen, J., Orcutt, J. D. Jr. (1982). The effect of food concentration on swimming patterns, feeding behavior, ingestion, assimilation, and respiration by Daphnia. Limnol. Oceanogr. 27 935-949 
Reeve, M. R. (1963). The filter-feeding of Artemia. II. In suspensions of various particles. J. exp. Biol. 40: 207-214

Rice, M. A., Wallis, K., Stephens, G. C. (1980). Influx and netflux of amino acids into larval and juvenile European flat oysters, Ostrea edulis L. J. exp. mar. Biol. Ecol. 48: $51-59$

Rigler, F. H. (1961). The relation between concentration of food and feeding rate of Daphnia magna Straus. Can. J. Zool. 39: 857-868

Riisgård, H. U., Randløv, A., Kristensen, P. S. (1980). Rates of water processing, oxygen consumption and efficiency of particle retention in veligers and young post-metamorphic Mytilus edulis. Ophelia 19: 37-47

Riisgård, H. U., Poulsen, E. (1981). Growth of Mytilus edulis in net bags transferred to different localities in a eutrophicated Danish fjord. Mar. Pollut. Bull. 12: 272-276

Riisgård, H. U., Randløv, A., Hamburger, K. (1981). Oxygen consumption and clearance in Mytilus edulis L. veliger larvae of different size. Ophelia 20: 179-185

Schlosser, H. J., Anger, K. (1982). The significance of some methodological effects on filtration and ingestion rates of the rotifer Brachionus plicatilis. Helgoländer Meeresunters. 35: 215-225

Sprung, M. (1984a). Physiological energetics of mussel larvae (Mytilus edulis). I. Shell growth and biomass. Mar. Ecol. Prog. Ser. 17, 283-293

Sprung, M. (1984b). Physiological energetics of mussel larvae (Mytilus edulis). III. Respiration. Mar. Ecol. Prog. Ser. 18 (in press)

Sprung, M. (1984c). Experiments on nutritional stress on the larvae of the mussel Mytilus edulis L. In: Gray, J. S., Christiansen, M. E. (ed.) Eighteenth European Marine Biology Symposium, Oslo. Wiley, Chichester (in press)

Stickney, A. P. (1964). Salinity, temperature, and food requirements of soft-shell clam larvae in laboratory culture. Ecology 45: 283-291

Strathmann, R. R., Jahn, T, L., Fonseca, J. R. C. (1972). Suspension feeding by marine invertebrate larvae: clearance of particles by ciliated bands of a rotifer, pluteus, and trochophore. Biol. Bull. mar. biol. Lab., Woods Hole 142: 505-519

Thorson, G. (1946). Reproduction and larval development of Danish marine bottom invertebrates. Meddr Kommn Danm. Fisk.-og Havunders., Ser. Plankton 4: 1-523

Thorson, G. (1950). Reproduction and larval ecology of marine bottom invertebrates. Biol. Rev. 25: 1-45

Throndsen, J. (1978). Productivity and abundance of ultraand nanoplankton in Oslofjorden. Sarsia 63: 273-284

Tubiash, H. S. Chanley, P. E., Leifson, E. (1965). Bacterial necrosis, a disease of larval and juvenile bivalve molluscs. J. Bact. 90: 1036-1044

Tubiash, H. S. (1972). Bacterial pathogens associated with cultured bivalve mollusk larvae. In: Smith, W. L., Chanley, M. H. (ed.) Culture of marine invertebrate animals. Plenum Press, New York, p. 61-71
Ukeles, R. (1975). Views of bivalve larvae nutrition. In: Price, K. S. Jr., Shaw, W N., Danberg, K. S. (ed.) Proceedings of the first conference on aquaculture nutrition. University of Delaware, Newark, p. 127-162

Walne, P. R. (1956). Experimental rearing of the larvae of Ostrea edulis L. in the laboratory. Fishery Invest., Lond. II, 20: $1-23$

Walne, P. R. (1958). The importance of bacteria in laboratory experiments on rearing the larvae of Ostrea edulis (L.) J. mar biol Ass. U. K. 37: 415-425

Walne, P. R. (1959). Some observations on the feeding behaviour of oyster (Ostrea edulis) larvae and their relation to rearing problems. Proc. 15th Int. Congr. Zool., London: $234-236$

Walne, P. R. (1963). Observations on the food value of seven species of algae to the larvae of Ostrea edulis. J. mar. biol Ass. U. K. 43: $767-780$

Walne, P. R. (1964). The culture of marine bivalve larvae. In: Wilbur, K. M., Yonge, C. M. (ed.) Physiology of mollusca, Vol. I. Academic Press, New York, p. 197-210

Walne, P. R. (1965). Observations on the influence of food supply and temperature on the feeding and growth of the larvae of Ostrea edulis. Fishery Invest., Lond. II, 24: 1-45

Walne, P. R. (1966). Experiments in the large scale culture of the larva of Ostrea edulis L. Fishery Invest., Lond. II, 25: $1-53$

Walne, P. R. (1970). Studies on the food value of nineteen genera of algae to juvenile bivalves of the genera Ostrea, Crassostrea, Mercenaria and Mytilus. Fishery Invest., Lond. II, 26: 1-61

Walne, P. R. (1979). Culture of bivalve molluscs. 50 years of experience at Conwy. Fishing News Books Ltd, Farnham

Walz, N. (1978). The energy balance of the freshwater mussel Dreissena polymorpha Pallas in laboratory experiments and in Lake Constance. I. Pattern of activity, feeding and assimilation. Arch. Hydrobiol. 55 (Suppl.): 83-105

Wenzel, F., Liebisch, H. (1975). Quantitative Untersuchungen zur Nahrungsaufnahme von Stentor coerulus Ehrenberg Zool. Anz. 195: 319-337

Wilson, J. H. (1980). Particle retention and selection by larvae and spat of Ostrea edulis in algal suspensions. Mar. Biol. 57. $135-145$

Winter, J. E. (1973). The filtration rate of Mytilus edulis and its dependence on algal concentration, measured by a continuous automatic recording apparatus. Mar. Biol. 22: 317-328

Winter, J. E. (1978). A review on the knowledge of suspension-feeding in lamellibranchiate bivalves, with special reference to artificial aquaculture systems. Aquaculture 13: 1-33

Yonge, C. M. (1926). Structure and physiology of the organs of feeding and digestion in Ostrea edulis. J. mar. biol. Ass U. K. 14: 295-386 